\title{
UJI KECEPATAN RASPBERRY PI SEBAGAI PRIVATE CLOUD STORAGE UNTUK SMALL OFFICE HOME OFFICE: DENGAN STUDI KASUS DI UPT TIK
}

\author{
Ferdinand Louis ${ }^{1}$, M. Ficky Duskarnaen², Hamidillah Ajie ${ }^{3}$ \\ ${ }^{1}$ Mahasiswa Prodi PendidikanTeknik Informatika dan Komputer, Teknik Elektro, FT - UNJ \\ ${ }^{2,3}$ Dosen Prodi Pendidikan Teknik Informatika dan Komputer, Teknik Elektro, FT - UNJ \\ 1'flou.louis@gmail.com, ${ }^{2}$ duskarnaen@unj.ac.id, ${ }^{3}$-hamidillah@unj.ac.id
}

\begin{abstract}
Abstrak
Small Office Home office atau SOHO adalah sebutan bagi sebuah entitas bisnis berukuran kecil dengan jumlah karyawan tidak lebih dari sepuluh orang. Sebuah soho umumnya merupakan berupa bisnis rintisan yang memiliki keterbatasan dalam pendanaan untuk pengadaan media penyimpanan terpusat. Untuk mengatasi permasalahan tersebut SOHO biasanya menggunakan layanan komputasi awan yaitu public cloud storage yang dimana akan digunakan sebuah server virtual dari penyedia layanan sebagai tempat pencadangan data kantor. Namun pada layanan public cloud storage pemilik bisnis tidak mendapat jaminan secara konkret jika data yang tersimpan pada server penyedia layanan tidak dapat dilihat oleh pihak dari luar kantor. Oleh karena itu peneliti berencana membuat sebuah private cloud storage menggunakan perangkat Raspberry PI 3B+ yang berukuran ringkas sehingga mudah disimpan, dan bersifat eksklusif hanya untuk individu di dalam entitas bisnis. Purwarupa ini diharapkan dapat memenuhi kebutuhan sebuah Small Office Home Office akan penyimpanan terpusat yang handal, aman, dan praktis dalam penerapannya. Pengembangan perangkat menggunakan metode purwarupa, spesifikasi Raspberry Pi yang digunakan masuk dalam golongan low-budget server. Penelitian diawali dengan menganalisa kebutuhan SOHO, lalu dilanjutkan dengan mendesain purwarupa seperti penggunaan kustomisasi yang diperlukan perangkat dan penerapan pada kondisi riil untuk diujikan kembali. Pengujian dilakukan untuk mengukur kecepatan dan membandingkan kecepatan transfer hasil pengujian dengan estimasi kecepatan yang dibutuhkan untuk layanan cloud computing pada SOHO. Private cloud storage pada penelitian ini menunjukan hasil bahwa transfer data belum optimal memenuhi kebutuhan penyimpanan terpusat dengan 10 user dan 2 akses ISP.
\end{abstract}

Kata kunci : Small Office Home Office, Cloud Storage, Raspberry Pi

\section{Pendahuluan}

\subsection{Latar Belakang}

Komputasi awan atau cloud computing, merupakan salah satu contoh gabungan pemanfaatan teknologi komputer dan pengembangan berbasis Internet. Komputasi awan memanfaatkan Internet sebagai pusat pengelolaan data dan aplikasi, dimana pengguna dimungkinkan untuk menggunakan layanan software, media penyimpanan (storage), platform infrastruktur dan aplikasi layanan teknologi lainnya melalui jaringan Internet.Penerapan teknologi komputasi awan, memungkinkan pengguna menghemat biaya untuk perangkat komputer dan infrastruktur pendukungnya baik software maupun hardware.

Cloud storage merupakan salah satu jenis layanan dari cloud computing sebagai Infrastructure as a Service yang memberikan layanan penyimpanan data terpusat secara virtual sehingga mampu mengurangi penggunaan media penyimpanan fisik seperti hard disk dan flash drive. Penggunaan cloud storage sebagai penyimpanan data juga dapat mengurangi kemungkinan file tercecer dan mengurangi kemungkinan rusaknya file hingga mengurangi juga kemungkinan kontaminasi virus pada file akibat proses transfer data menggunakan media penyimpanan external.

Public cloud storage merupakan salah satu jenis cloud storage yang menyediakan layanan berupa pengaksesan data tersimpan setiap waktu dan dari semua tempat yang berbasis pada Internet. Layanan public cloud storage disediakan oleh berbagai vendor seperti Google, Microsoft, Mega, dan Dropbox. Data pengguna akan tersimpan dan terpusat pada server tiap-tiap vendor disertai dengan beberapa server backup.

Private cloud storage merupakan salah satu jenis cloud storage yang memungkinkan pengguna untuk melakukan pengaksesan data setiap waktu dan 
dari semua tempat, maupun secara local pada jaringan LAN (Local Area Network) tanpa koneksi Internet sehingga dapat memberikan rasa aman lebih bagi pengguna.

Small Office Home Office (SOHO) merupakan isilah untuk sebuah bisnis kecil yang memiliki karyawan tidak lebih dari sepuluh orang, dan umumnya adalah bisnis rintisan yang memiliki pendanaan terbatas.

Unit Pelayanan Teknis Teknologi Informasi dan Komputer Universitas Negeri Jakarta merupakan salah satu Unit Pelayanan Teknis (UPT) yang terdapat pada Universitas Negeri Jakarta (UNJ) yang didirikan dengan tujuan mendukung kegiatan operasional UNJ dalam bidang teknologi informasi dan komunikasi (TIK). Kantor UPT TIK terbagi dalam dua bagian unit kerja yaitu kantor untuk tim Jaringan dan tim RPL atau software, yang dimana tiap-tiap unit tidak memiliki lebih dari sepuluh anggota, sehingga memenuhi pengkondisian sebagai $\mathrm{SOHO}$.

Dalam operasionalnya, UPT TIK banyak menggunakan aplikasi-aplikasi komputer seperti aplikasi Microsoft word dan Microsoft Excel yang data-datanya bersifat digital. Dalam kegiatanya, UPT TIK mengalami beberapa masalah yang timbul berkaitan dengan penggunaan data digital seperti file suatu proyek yang tercecer kedalam beberapa komputer atau media penyimpanan, hingga kerusakan file yang terjadi pada proses perpindahan data dari komputer ke media penyimpanan seperti flash drive, maupun kerusakan file yang diakibatkan oleh virus.

Raspberry Pi merupakan sebuah komputer papan tunggal yang berukuran kecil sebesar sebuah kartu kredit. Raspberry Pi memiliki kelebihan dibandingkan dengan komputer pada umumnya, yaitu ukurannya yang kecil membuatnya ringkas dan praktis untuk pemasangannya, selain itu Raspberry Pi memiliki konsumsi daya yang jauh lebih kecil disbanding komputer pada umumnya, sehingga cocok untuk digunakan sebagai induk dari private cloud storage.

ownCloud merupakan aplikasi open source yang menyajikan layanan cloud storage, dengan ownCloud pengguna dapat menyimpan dan mengambil file melalui antar muka halaman web maupun aplikasi client.

Pemanfaatan private cloud storage menggunakan Raspberry Pi dengan ownCloud cocok untuk digunakan oleh jenis kantor berskala Small Office Home Office yang mana masih memiliki pendanaan terbatas, belum mampu untuk membeli server khusus sebagai pusat penyimpanan data serta tempat untuk menampungnya, namun memerlukan media penyimpanan private berbasis cloud.

Salah satu contoh kasus pemanfaatan Raspberry Pi sebagai private cloud storage pada
UPT TIK adalah sebagai tempat pengumpulan tugas akhir mata kuliah yang berbentuk file atau folder digital. Dosen cukup memberikan link kepada mahasiswa untuk melakukan upload file atau folder tugas akhir. Sehingga jauh lebih aman dan praktis dalam prosesnya ketimbang mengedarkan media penyimpanan fisik seperti flash drive ke seluruh PC/ laptop mahasiswa yang memiliki risiko lebih besar tercemar virus maupun terjadinya kerusakan data (corrupt).

\subsection{Identifikasi Masalah}

1. Proses transfer data menggunakan media fisik seperti flash drive dan hard disk tidak praktis untuk digunakan pada banyak komputer karena memerlukan waktu yang lama.

2. Risiko kontaminasi virus pada media penyimpanan external ketika dihubungkan dengan komputer.

\subsection{Batasan Masalah}

1. Perangkat private cloud storage dirancang pada Raspberry Pi 3 B+ dengan media penyimpanan external hard disk.

2. Pemanfaatan utama media private cloud storage untuk layanan file sharing, back up data, dan sinkronisasi.

3. Jenis file yang akan digunakan sebagai instrumen ujian adalah file text, gambar, suara, suara, suara-gambar.

\subsection{Rumusan Masalah}

Berdasarkan proses latar belakang masalah, identifikasi dan Batasan masalah, maka perumusan masalah yan akan dibahas pada penelitian ini adalah: Layak atau tidaknya penggunaan Raspberry $\mathrm{Pi}$ sebagai server private cloud storage untuk Small Office Home Office.

\subsection{Tujuan Penelitian}

Tujuan yang diharapkan akan dicapai pada penelitian ini adalah untuk menghasilkan private cloud storage sebagai media penyimpanan handal untuk mengatasi peroses perpindahan data secara massif dengan tingkat keamanan yang baik dan praktis dalam proses penerapan dan pengoprasiannya.

\subsection{Manfaat Penelitian}

Manfaat penelitian ini dapat dikategorikan menjadi dua, yaitu manfaat secara teoritis dan manfaat secara praktis:

1. Secara teoritis, hasil dari penelitian ini diharapkan dapat dimanfaatkan sebagai referensi dan acuan dalam pengembangan sistem cloud tertutup pada Small Office Home Office. 
2. Secara Praktis, hasil dari penelitian ini diharapkan dapat dijadikan sebagai bahan pengembangan private cloud untuk lingkup Small Office Home Office.

\section{Dasar Teori}

\subsection{Jaringan Internet}

Internet secara umum didefinisikan sebagai jaringan komputer terbesar di dunia yang menghubungkan seuma jaringan komputer yang ada (Intranet, Wide Area Network, Metropolitan Area Network, Personal Area Network, dan lain-lain) beserta dengan semua komputer, perangkat terhubung (smartphone, tablet, komputer benam, switch, router, hub, dan perangkat penghubung lainnya), serta pengguna komputer itu sendiri, ke dalam satu wadah jaringan komputer dunia (Pratama, 2015).

\subsection{Small Office Home Office}

Soho adalah usaha kecil yang sering kali dijalankan dari rumah atau bahkan secara virtual. Mereka biasanya memiliki kurang dari 10 karyawan. SOHO dianggap sebagai usaha mikro, dan pemiliknya sering berwiraswasta atau bekerja dari jarak jauh (Kenton, 2019)

\subsection{Estimasi Bandwidth Small Office Home Office}

Estimasi bandwidth yang dibutuhkan oleh setiap individu pada perkantoran untuk melakukan cloud backup, cloud-based services, file sharing, dan data transfer berkisar dari 2 Mbps untuk cloud backup dan data transfer hingga 5 Mbps untuk file sharing dan cloud-based services lainnya (Verizon, 2018).

\subsection{Network Attached Storage}

Network Attached Storage (NAS) adalah media penyimpanan yang terhubung kejaringan dan menyediakan layanan akses file. Perangkat NAS pada dasarnya terdiri dari disk drive yang menyimpan file dan pengontrol yang mengekspor layanan akses ke file. (Kazuo, 2019).

\subsection{Cloud Computing}

Cloud computing adalah sebuah model yang memungkinkan adanya penggunaan sumber daya (resource) secara Bersama-sama dan mudah, menyediakan jaringan akses dimana-mana, dapat dikonfigurasi, dan layanan yang digunakan sesuai keperluan (on demand). Hal ini berarti layanan pada cloud computing dapat disediakan dengan cepat dan meminimalisir interaksi dengan penyedia layanan (vendor/provider) cloud computing (Mell dan Grance, 2011).

\subsection{Deployment Model Cloud Computing}

Terdapat empat deployment model cloud computing yaitu private cloud, community cloud, public cloud, dan hybrid cloud.

1. Private cloud, infrastruktur cloud disediakan untuk penggunaan eksklusif oleh satu organisasi terdiri dari banyak konsumen (misalnya, unit bisnis).

2. Community cloud, infrastruktur cloud disediakan untuk penggunaan eksklusif oleh spesifik komunitas konsumen dari organisasi yang dimiliki persoalan bersama (misalnya misi, persyaratan keamanan, kebijakan, dan pertimbangan kepatuhan).

3. Public cloud, infrastruktur cloud disediakan untuk penggunaan terbuka oleh masyarakat umum. Infrastruktur cloud dapat dimiliki, dikelola, dan di operasikan oleh bisnis, akademik, atau organisasi pemerintah, atau beberapa kombinasinya. Infrastruktur berada di lokasi penyedia layanan cloud.

4. Hybrid cloud, infrastruktur cloud merupakan kombinasi dari dua atau lebih model cloud yang berbeda infrastruktur (private, community, atau public) yang tetap merupakan entitas unik, tetapi terika bersama oleh teknologi yang terstandarisasi atau eksklusif yang memungkinkan portabilitas data dan aplikasi (misalnya, cloud bursting untuk load balancing antar cloud). (Mell dan Grance, 2011).

\subsection{Cloud Storage}

Cloud storage adalah model penyimpanan online di mana data disimpan di beberapa server virtual, umumnya dihosting oleh pihak ketiga, bukan di host di server khusus. (Balbudhe, Pravin O. et al, 2013).

\section{8. ownCloud}

ownCloud merupakan aplikasi open source oleh ownCloud Inc., yang mendukung teknologi cloud computing. ownCloud menyajikan layanan cloud storage, yaitu layanan penyimpanan dan pengambilan file secara online melalui jaringan cloud computing.

\subsection{Raspberry $\mathbf{P i}$}

Raspberry Pi adalah computer papan tunggal (single-board circuit) yang sukuran dengan kartu kredit yang dapat digunakan untuk menjalankan program perkantoran, permainan computer, dan sebagai pemutar media hingga video berresolusi tinggi. Raspberry Pi dikembangkan oleh Yayasan nirlaba, Raspberry Foundation, yang digawangi sejumlah pengembang dan ahli computer dari Universitas Cambridge, Inggris. 


\subsection{Raspbian OS}

Raspbian $O S$ adalah system operasi yang berbasis pada sistem operasi Debian untuk Raspberry Pi.

\subsection{Port Forwarding}

Port forwarding adalah sebuah metode menyambungkan perangkat dalam jaringan ke jaringan yang lebih luas.

\section{Metodologi}

Perangkat keras yang digunakan dalam penelitian ini adalah sebuah notebook merk Lenovo tipe Y700 dan Raspberry Pi dengan spesifikasi perangkat keras dan daftar perangkat lunak yang digunakan ditunjukkan pada Tabel 3.1.

Tabel 3.1. Alat Penelitian

\begin{tabular}{|c|c|c|}
\hline No. & Perangka Keras & Perangkat Lunak \\
\hline 1. & $\begin{array}{lll}\text { Intel } \mathbb{B} \text { Core } & \text { TM } & i 7-6700 \mathrm{HQ} \\
\text { Processor } & (2.6 \mathrm{GHz}, & 6 \mathrm{M} \\
\text { Cache. } & \text { Max } & \text { Turbo } \\
\text { Frequency } & 3.5 \mathrm{GHz})\end{array}$ & $\begin{array}{l}\text { Windows } 10 \text { Home 64-bit (1803, Build } \\
17134.706)\end{array}$ \\
\hline 2. & 16GB DDR4 RAM & Raspbian OS Stretch \\
\hline 3. & $\begin{array}{l}\text { NVIDIA® GeForce } ® \text { GTX } \\
960 M 4 G B \text { GDDR5 }\end{array}$ & OwnCloud Server 10.1.1 \\
\hline 4. & 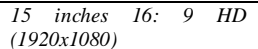 & $\begin{array}{l}\text { Google Chrome Versi } 69.0 .3497 .100 \\
\text { (Official Build) (64-bit) }\end{array}$ \\
\hline 5. & ITB SATA HDD & VNC Viewer 6.19 .235 Windows \\
\hline 6. & 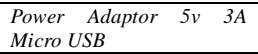 & VNC Viewer 6.19.235 Linux-ARM.deb \\
\hline 7. & & \\
\hline 8. & $\begin{array}{l}\text { ARM Cortex-A53 } 1.4 \mathrm{GHz} \\
\text { Processor }\end{array}$ & OwnCloud Desktop Client Versi 2.5.4 \\
\hline 9. & I GB SRAM & \\
\hline 10. & Raspberry Pi ABS Case & \\
\hline 11. & Mini Cooling Fan DC 5V & \\
\hline 12. & $\begin{array}{l}\text { Core Switch Cisco Catalyst } \\
6800\end{array}$ & \\
\hline 13. & $\begin{array}{l}\begin{array}{l}\text { Distribution Switch Cisco } \\
\text { Catalyst } 3850125\end{array} \\
\end{array}$ & \\
\hline 14. & $\begin{array}{l}\text { Access Switch Cisco } 2960 \\
24 T S\end{array}$ & \\
\hline 15. & SMB Switch SG220-50 & \\
\hline 16. & Intel Core i3-3220 $3.3 \mathrm{GHz}$ & \\
\hline 17. & 4GB DDR3 RAM & \\
\hline 18. & $\begin{array}{llll}\begin{array}{l}\text { Windows } \\
17763\end{array} & 10 & \text { Pro } & \text { Build } \\
\end{array}$ & \\
\hline
\end{tabular}

Penelitian dilakukan dengan menggunakan metode purwarupa dalam perancangan dan penerapan private cloud storage.

Pada bagian ini dijelaskan tentang perancangan dan bagaimana cara/ langkah-langkah melakukan penelitian atau perancangan yang telah dilakukan tersebut. Gambaran mengenai cara melakukan penelitian atau perancangan ada kalanya akan lebih baik jika direpresentasikan dalam bentuk diagram alir.

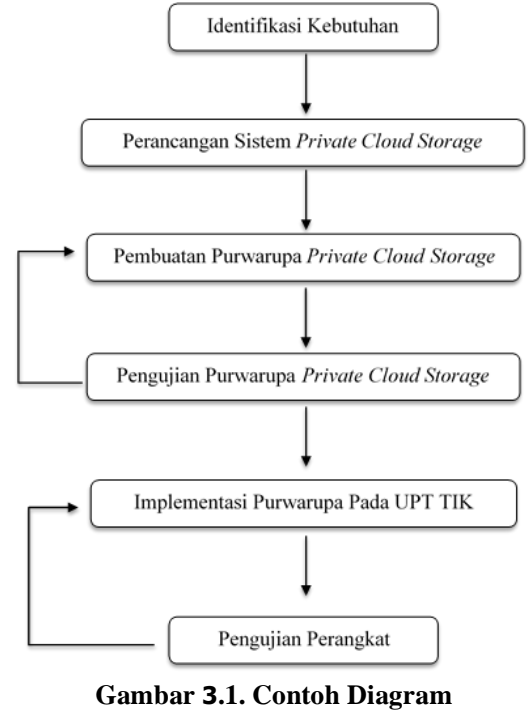

Tahap awal dalam perancangan produk, penulis memetakan identifikasi kebutuhan jenis-jenis user dan apa saja kemampuannya. Setelah kebutuhan terpetakan, penulis melakukan perancangan berupa kustomisasi pada raspberry pi dan perancangan sistem kerja private cloud storage meliputi metode transfer data yang dapat digunakan pada private cloud storage, kapasitas penyimpanan tiap-tiap user pada sistem, serta ukuran media penyimpanan fisik yang diperlukan.

Tahap selanjutnya adalah pembuatan purwarupa awal dilakukan dengan melakukan proses instalisasi dan konfigurasi pada sistem private cloud storage berdasarkan hasil rancangan sistem yang telah dibuat pada tahap sebelumnya.

Pengujian dilakukan dengan metode black box dengan focus pada pengujian kecepatan. Proses pengujian dikatakan berhasil apabila purwarupa dapat berfungsi dengan baik, dan memenuhi standar yang telah dibuat yaitu dapat menangani setidaknya sepuluh client secara bersamaan. Apabila purwarupa tidak memenuhi standar yang telah dibuat atau dikatakan kurang bagus, maka purwarupa akan diperbaiki untuk diuji kembali.

Setelah purwarupa lolos proses pengujian, purwarupa akan diimplementasikan pada jaringan UPT TIK, dan menyesuaikan dengan topology jaringan UPT TIK yang sudah ada. Pada tahap terakhir ini, purwarupa yang telah dipasang pada topology UPT TIK akan di uji untuk memastikan perangkat sebagai produk akhir dapat berjalan sesuai dengan baik pada kondisi aslinya.

\section{Hasil dan Analisis}

Penelitian ini menghasilkan produk berupa perangkat private cloud storage berbasi Raspberry $\mathrm{Pi}$ untuk Small Office Home Office. Produk nantinya akan menjalani pengujian kecepatan untuk 
mengetahui berapa kecepatan transfer file oleh beberap auser secara bersamaan. Adapun hasil pengujian produk dapat dilihat pada Tabel 4.1 dan Tabel 4.3:

\begin{tabular}{|c|c|c|c|c|c|c|c|c|}
\hline \multirow[t]{2}{*}{ PC 1} & \multicolumn{4}{|c|}{ Download Mbps } & \multicolumn{4}{|c|}{ Upload Mbps } \\
\hline & Word & Gambar & Video & Audio & Word & Gambar & Video & Audio \\
\hline Highest & 13,6 & 5,6 & 7,2 & 6,4 & 10,4 & 10,4 & 10,4 & 11,2 \\
\hline Average & 12,8 & 5,6 & 5,6 & 5,6 & 7,2 & 8,8 & 6,4 & 5,6 \\
\hline Lowest & 12 & 3,2 & 4,8 & 4,8 & 4 & 3,2 & 1,6 & 2,4 \\
\hline $\begin{array}{l}\text { Kondisi } \\
\text { File } \\
\text { (Utuh/ } \\
\text { Rusak) }\end{array}$ & Utuh & Utuh & Utuh & Utuh & Utuh & Utuh & Utuh & Utuh \\
\hline \multirow[t]{2}{*}{ PC 2} & \multicolumn{4}{|c|}{ Download Mbps } & \multicolumn{4}{|c|}{ Upload Mbps } \\
\hline & Word & Gambar & Video & Audio & Word & Gambar & Video & Audio \\
\hline Highest & 24 & 12 & 16 & 17,6 & 9,6 & 20 & 10,4 & 16,8 \\
\hline Average & 11,2 & 11,2 & 11,2 & 9,6 & 5,6 & 7,2 & 7,2 & 6,4 \\
\hline Lowest & 4,8 & 10,4 & 10,4 & 6,4 & 2,4 & 1,6 & 0,8 & 4,8 \\
\hline \multirow[t]{2}{*}{$\begin{array}{c}\text { Kondisi } \\
\text { File } \\
\text { (Utuh / } \\
\text { Rusak) }\end{array}$} & Utuh & Utuh & Utuh & Utuh & Utuh & Utuh & Utuh & Utuh \\
\hline & Word & Gambar & Video & Audio & Word & Gambar & Video & Audio \\
\hline Highest & 28,8 & 12 & 16,8 & 12,8 & 12 & 35,2 & 10,4 & 10,4 \\
\hline Average & 10,4 & 4,8 & 11,2 & 12 & 5,6 & 12 & 5,6 & 6,4 \\
\hline Lowest & 2,4 & 3,2 & 2,4 & 1,6 & 3,2 & 0 & 0 & 0 \\
\hline $\begin{array}{c}\text { Kondisi } \\
\text { File } \\
\text { (Utuh / } \\
\text { Rusak) }\end{array}$ & Utuh & Utuh & Utuh & Utuh & Utuh & Utuh & Utuh & Utuh \\
\hline PC 4 & \multicolumn{4}{|c|}{ Download Mbps } & \multicolumn{4}{|c|}{ Upload Mbps } \\
\hline & Word & Gambar & Video & Audio & Word & Gambar & Video & Audio \\
\hline Highest & 32,8 & 28,8 & 42,4 & 13,6 & 13,6 & 25,6 & 12 & 12,8 \\
\hline Average & 10,4 & 11,2 & 19,2 & 12 & 4,8 & 11,2 & 6,4 & 4,8 \\
\hline Lowest & 3,2 & 2,4 & 4 & 3,2 & 2,4 & 0 & 0 & 0 \\
\hline $\begin{array}{c}\text { Kondisi } \\
\text { File } \\
\text { (Utuh / } \\
\text { Rusak) }\end{array}$ & Utuh & Utuh & Utuh & Utuh & Utuh & Utuh & Utuh & Utuh \\
\hline PC 5 & \multicolumn{4}{|c|}{ Download Mbps } & \multicolumn{4}{|c|}{ Upload Mbps } \\
\hline & Word & Gambar & Video & Audio & Word & Gambar & Video & Audio \\
\hline Highest & 12,8 & 21,6 & 17,6 & 12,8 & 9,6 & 12 & 22,4 & 14,4 \\
\hline Average & 12 & 7,2 & 12 & 12 & 5,6 & 8,8 & 14,4 & 9,6 \\
\hline Lowest & 11,2 & 7,2 & 7,2 & 11,2 & 1,6 & 6,4 & 5,6 & 4,8 \\
\hline $\begin{array}{c}\text { Kondisi } \\
\text { File } \\
\text { (Utuh/ } \\
\text { Rusak) }\end{array}$ & Utuh & Utuh & Utuh & Utuh & Utuh & Utuh & Utuh & Utuh \\
\hline PC 6 & \multicolumn{4}{|c|}{ Download Mbps } & \multicolumn{4}{|c|}{ Upload Mbps } \\
\hline
\end{tabular}

\begin{tabular}{|c|c|c|c|c|c|c|c|c|}
\hline & Word & Gambar & Video & Audio & Word & Gambar & Video & Audio \\
\hline Highest & 21,6 & 30,4 & 12,8 & 20,8 & 11,2 & 20 & 22,4 & 15,2 \\
\hline Average & 7,2 & 4,8 & 12 & 7,2 & 6,4 & 8 & 14,4 & 10,4 \\
\hline Lowest & 4 & 4 & 11,2 & 6,4 & 1,6 & 1,6 & 9,6 & 4,8 \\
\hline $\begin{array}{c}\text { Kondisi } \\
\text { File } \\
\text { (Utuh/ } \\
\text { Rusak) }\end{array}$ & Utuh & Utuh & Utuh & Utuh & Utuh & Utuh & Utuh & Utuh \\
\hline PC 7 & \multicolumn{4}{|c|}{ Download Mbps } & \multicolumn{4}{|c|}{ Upload Mbps } \\
\hline & Word & Gambar & Video & Audio & Word & Gambar & Video & Audio \\
\hline Highest & 4,8 & 12 & 23,2 & 17,6 & 9,6 & 10,4 & 10,4 & 37,6 \\
\hline Average & 4 & 11,2 & 4,8 & 4,8 & 8 & 4,8 & 6,4 & 8 \\
\hline Lowest & 3,2 & 10,4 & 4 & 3,2 & 3,2 & 0,8 & 1,6 & 5,6 \\
\hline $\begin{array}{c}\text { Kondisi } \\
\text { File } \\
\text { (Utuh/ } \\
\text { Rusak) }\end{array}$ & Utuh & Utuh & Utuh & Utuh & Utuh & Utuh & Utuh & Utuh \\
\hline PC 8 & \multicolumn{4}{|c|}{ Download Mbps } & \multicolumn{4}{|c|}{ Upload Mbps } \\
\hline & Word & Gambar & Video & Audio & Word & Gambar & Video & Audio \\
\hline Highest & 12,8 & 11,2 & 22,4 & 18,4 & 13,6 & 9,6 & 9,6 & 35,2 \\
\hline Average & 12,4 & 10,8 & 4,8 & 4,8 & 10,4 & 4,8 & 7,2 & 7,2 \\
\hline Lowest & 12 & 10,4 & 4 & 3,2 & 6,4 & 0,8 & 1,6 & 3,2 \\
\hline $\begin{array}{l}\text { Kondisi } \\
\text { File } \\
\text { (Utuh/ } \\
\text { Rusak) }\end{array}$ & Utuh & Utuh & Utuh & Utuh & Utuh & Utuh & Utuh & Utuh \\
\hline PC 9 & \multicolumn{4}{|c|}{ Download Mbps } & \multicolumn{4}{|c|}{ Upload Mbps } \\
\hline & Word & Gambar & Video & Audio & Word & Gambar & Video & Audio \\
\hline Highest & 20 & 16 & 14,4 & 15,2 & 14,4 & 12 & 20 & 12 \\
\hline Average & 14,4 & 12 & 12 & 12 & 4 & 8 & 10,4 & 8 \\
\hline Lowest & 9,6 & 9,6 & 9,6 & 8,8 & 0 & 0 & 0 & 0 \\
\hline $\begin{array}{l}\text { Kondisi } \\
\text { File } \\
\text { (Utuh/ } \\
\text { Rusak) }\end{array}$ & Utuh & Utuh & Utuh & Utuh & Utuh & Utuh & Utuh & Utuh \\
\hline PC 10 & \multicolumn{4}{|c|}{ Download Mbps } & \multicolumn{4}{|c|}{ Upload Mbps } \\
\hline & Word & Gambar & Video & Audio & Word & Gambar & Video & Audio \\
\hline Highest & 17,6 & 10,4 & 14,4 & 17,6 & 12 & 8 & 21,6 & 17,6 \\
\hline Average & 9,6 & 4,8 & 12 & 6,4 & 4 & 4 & 9,6 & 9,6 \\
\hline Lowest & 6,4 & 4 & 9,6 & 4,8 & 0 & 0 & 0 & 0 \\
\hline $\begin{array}{c}\text { Kondisi } \\
\text { File } \\
\text { (Utuh/ } \\
\text { Rusak) } \\
\end{array}$ & Utuh & Utuh & Utuh & Utuh & Utuh & Utuh & Utuh & Utuh \\
\hline
\end{tabular}

Tabel 4.2. Pengujian Kecepatan Download dan Upload Multifile oleh Empat User Bersamaan

\begin{tabular}{|c|c|c|c|c|c|c|c|c|}
\hline PC 1 & \multicolumn{5}{|c|}{ Download Mbps } & \multicolumn{4}{|c|}{ Upload Mbps } \\
\hline & Word & Gambar & Video & Audio & Word & Gambar & Video & Audio \\
\hline Speed & 20,5 & 21,7 & 20,9 & 21,3 & 14,3 & 9,3 & 10,1 & 12,2 \\
\hline $\begin{array}{c}\text { Kondisi } \\
\text { File } \\
\text { (Utuh/ } \\
\text { Rusak) }\end{array}$ & Utuh & Utuh & Utuh & Utuh & Utuh & Utuh & Utuh & Utuh \\
\hline
\end{tabular}




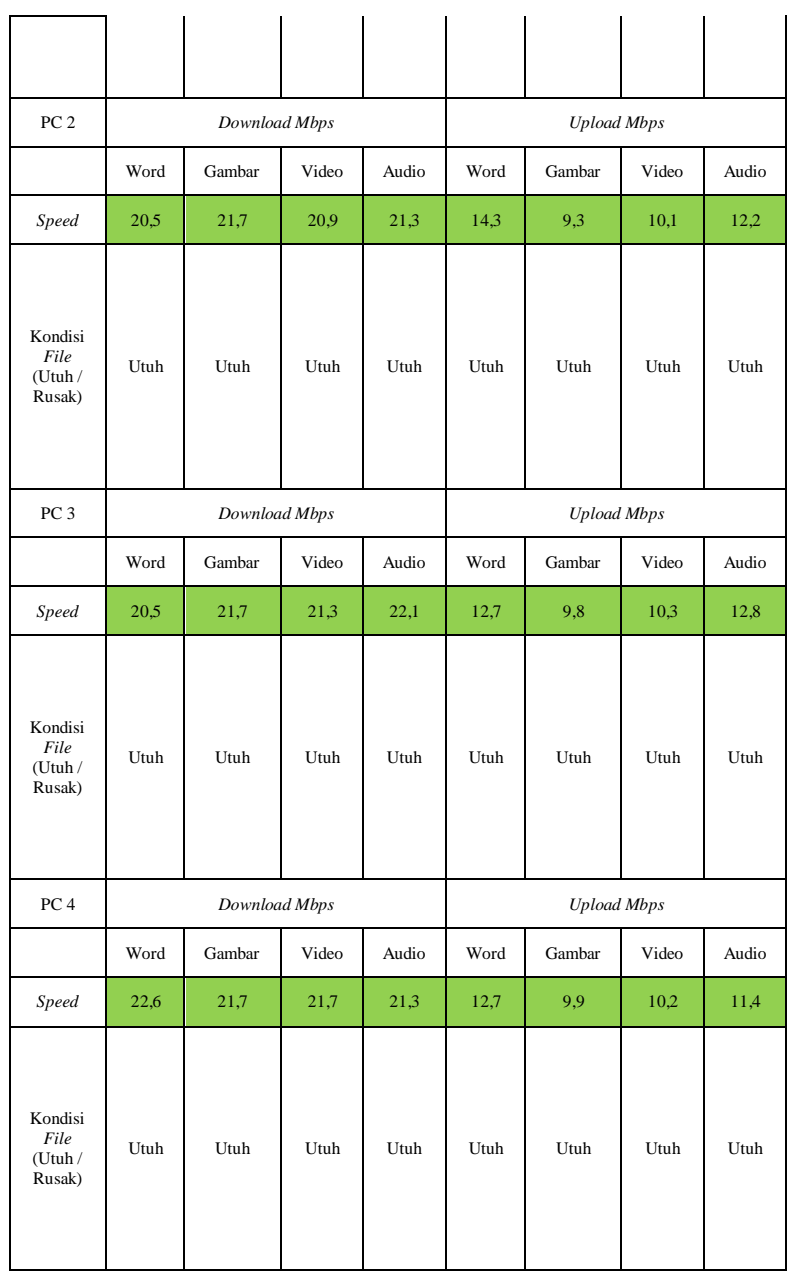

\subsection{Pembahasan}

Pengujian dilakukan oleh 5 orang karyawan UPT TIK yaitu Achmad Ahlar Ridha, Erwin Firmansyah, Arif Budi Setiawan, Naufal Ibnu Salam, dan Febriano Widyoutomo pada tanggal 29 Juni 2019. Pengujian menggunakan 10 komputer yang berspesifikasi serupa. Pada pengujian satu file berukuran besar, seluruh file yang ditransmisikan tidak mengalami kerusakan dalam prosesnya, namun terjadi penurunan kecepatan transmisi baik pada proses download maupun upload seiring bertambahnya jumlah user, hal ini dikarenakan keterbatasan bandwidth pada perangkat Raspberry Pi yaitu sebesar 100 Mbps yang akan dibagi untuk untuk melayani 1,2,4,6,8, dan 10 user.

Untuk pengujian kedua yaitu menggunakan delapan buah file kecil yang total ukurannya sama dengan satu file pada pengujian pertama, terdapat penurunan kecepatan pada setiap pengujian bila dibandingkan dengan pengujian yang sama menggunakan satu file berukuran besar. Hal ini dikarenakan adanya overhead transfer berulang sebanyak delapan kali setiap user ( 8 file ) berbanding 1 pada pengujian pertama. Sehingga waktu untuk menunggu proses content negotiation selesai akan lebih lama. Lalu ketika dilakukan pengujian dengan delapan dan sepuluh user pengakses, didapati server mengalami freeze sehingga tidak dapat diakses. Hal ini dikarenakan server mengalami overload karena tidak bisa menangani tingginya traffic.

Untuk pengujian ketiga, dimana dua user menggunakan jaringan dari dua ISP yang berbeda yaitu First Media untuk PC 1 dan Indosat Ooredoo untuk PC2, didapati hasil bahwa kecepatan pengaksesan download maupun upload lebih lambat dibanding dengan pengaksesan pada jaringan yang sama. Hal ini dikarenakan adanya batasan bandwidth dari pihak ISP yaitu sebesar 10 Mbps untuk masingmasing ISP yang mengakibatkan kecepatan transfer file tidak bisa melebihi $10 \mathrm{Mbps}$

\section{Kesimpulan dan Saran}

Perangkat private cloud storage untuk small office home office ini dikembangkan menggunakan tahapan pada metode prototyping atau purwarupa. Perangkat ini dapat digunakan untuk melakukan backup data, file sharing, dan sinkronisasi file-file atau data-data perkantoran sebuah $\mathrm{SOHO}$.

Berdasarkan hasil pengujian kecepatan yang telah dilakukan untuk setiap jenis file, jumlah file yang berbeda, jumlah pengakses yang berbeda, dan pengaksesan menggunakan jaringan yang berbeda dari dua vendor Internet Service Provider perangkat sudah memenuhi standar kecepatan yang ditentukan. Sehingga dapat disimpulkan bahwa penggunaan Raspberry pi sebagai perangkat private cloud storage yang dibuat belum optimal untuk digunakan pada small office home office.

Adapun saran untuk dilakukan pengembangan lebih lanjut, antara lain sebagai berikut:

1. Penelitian selanjutnya diharapkan menggunakan perangkat raspberry pi generasi ke empat, karena adanya peningkatan kemampuan perangkat dalam hal processing power, transfer rate, serta nic yang telah support gigabit ethernet.

2. Untuk memperoleh hasil pengujian yang lebih optimum dan menunjang kemampuan raspberry pi terbaru, peneliti disarankan menggunakan kartu internet berkecepatan gigabit pada komputer client bersamaan dengan penggunaan gigabit switch.

\section{Daftar Pustaka:}

Balbudhe, Pravin O. 2013. Cloud storage Reference Model for Cloud computing. Diambil dari https://www.academia.edu/28655617/Cloud_ 
Storage_Reference_Model_for_Cloud_Comp uting/. Diakses pada tanggal 15 Maret 2019.

Budiyanto, Alex 2011. Pengantar Cloud computing. Diambil dari http://smuet.lecture.ub.ac.id/files/2012/06/EBook-Pengantar-Cloud-Computing-R1.pdf/. Diakses pada tanggal 4 Maret 2019.

Cioara, J., Minutella, D., Stevenson, H. 2007. CCNA Exam Prep. United States on America: Pearson Education, Inc.

Damjanovski, Vlado. 2014. The modern and Intelligent CCTV. Diambil dari https://www.academia.edu/37051028/The m odern and intelligent_CCTV/. Diakses Pada tanggal 26 Mei 2019.

Gao, Jerry. et al 2013. Testing and Quality Assurance for Component-based Software. Nordwood: Artech House, Inc.

Goda, Kazuo. 2009. Encyclopedia of Database Systems. Diambil dari https://link.springer.com/referenceworkentry/ 10.1007\%2F978-0-387-39940-9_1330/. Diakses pada tanggal 10 Maret 2019.

Irianingsih, Dwi P., Hendraini, Nina., Sularsa, Anang (2015). Implementasi Layanan Private Cloud storage Menggunakan ownCloud (Studi Kasus: PT. Magna Finance), 1(1):99104.

Kenton, Will. 2019. Small Office/Home Office (SOHO). Diambil dari https://www.investopedia.com/terms/s/smalloffice-home-office-soho.asp/. Diakses pada tanggal 25 Mei 2019.

Kholil, Moch., Mu'min, Syahri (2018). Pengembangan Private Cloud storage sebagai Sentralisasi Data Universitas Nahdlatul Ulama Sidoarja Berbasis Open Source Owncloud. Jurnal Ilmu Komputer dan Desain Komunikasi Visual, 3(1):33-41.

Kulkarni, G. et al 2012. A New Approach to Software as Service Cloud. Diambil dari https://www.researchgate.net/publication/239 732067_A_new_approach_to_Software_as_S ervice_Cloud/. Diakses Pada tanggal 4 Maret 2019.

Mell, Peter. \& Grance, Timothy. 2011. The Definition of Cloud computing. Diambil dari https://nvlpubs.nist.gov/nistpubs/Legacy/SP/n istspecialpublication800-145.pdf/. Diakses pada tanggal 3 Maret 2019.

Nidhra, Srinivas dan Dondeti Jagruthi (2012). Black Box and White Box Testing Techniques - A Literature Review. International Journal of Embedded Systems and Applications (UESA), 2(2).

O'Brien, James A. (2003). Introduction to Information System : Essentials for the E- business Enterprise. (11 ${ }^{\text {th }}$ edition). McGraw Hill Inc, New York.

Ostrand, Thomas 2002. Black-Box Testing. Diambil dari https://onlinelibrary.wiley.com/doi/10.1002/0 471028959.sof022/. Diakses pada tanggal 26 Mei 2019.

Owncloud.org. What is thi ownCloud thing ? Why would I care? [terhubung berkala]. Diambil dari https://owncloud.org/faq/\#whatis/. Diakses pada tanggal 12 April 2019.

Pittman, Ryan D. and Shaver Dave. 2010. Handbook of Digiral Forensics and Investigation. Diambil dari https://www.sciencedirect.com/book/978012 3742674/handbook-of-digital-forensics-andinvestigation/. Diakses pada tanggal $26 \mathrm{Mei}$ 2019.

Pratama, I Putu Agus Eka. 2014. Smart City Beserta Cloud computing dan Teknologiteknologi Pendukung Lainnya. Bandung: Informatika Bandung.

Pratama, I Putu Agus Eka. 2015. Handbook Jaringan Komputer Teori dan Praktik Berbasiskan Open Source. Bandung: Informatika Bandung.

Pratiwi, Mega D., Rosa Harise O., Simamora Antonius D (2015). Monitoring Performasi Private Cloud storage Menggunakan ownCloud. Jurnal e-Proceeding of Aplied Science, 1(1):105-111.

Pressman, R.S. 2010. Software Engineering: a Practitioner's Approach. Ed ke-7. New York: McGraw-Hill.

Raspberrypi.org. Raspbian. [terhubung berkala]. Diambil dari: https://www.raspberrypi.org/documentation/r aspbian/. Diakses pada tanggal 25 Mei 2019.

Raspberrypi.org. What is a Raspberry Pi? [terhubung berkala]. Diambil dari: https://www.raspberrypi.org/help/what\%20is-a-raspberry-pi/ Diakses pada tanggal 20 April 2019.

Rouse, Margaret. 2015. Prototyping Model. Diambil dari: https://searchcio.techtarget.com/definition/Pr ototyping-Model/. Diakses pada tanggal 25 Mei 2019.

Ulfa, Maria., Panjaitan, Febriyanti., Suryayusra (2018). Layanan Private Cloud computing Berbasis NextCloud. Jurnal Pengabdi, 1(2).

Verizon. 2018. How much bandwidth do I need for my business? Diambil dari https://go.verizon.com/resources/how-muchbandwidth-do-i-need-for-my-business/. Diakses pada tanggal 5 Juli 2019 
Ward, Susan. 2018. SOHOs Are the Most Numerous Type of Business. Diambil dari https://www.thebalancesmb.com/smalloffice-home-office-soho-2948189/. Diakses pada tanggal 12 Mei 2019.

Yousuf, Md. Adib Ibne \& Haque, Md. Atiqul. 2017. Cloud storage Course Code: Information Technology for Business Value. Diambil dari https://www.academia.edu/35514303/Cloud_Storage l. Diakses pada 16 nMaret 2019 